\title{
EFEKTIVITAS OMBUDSMAN PROVINSI KEPULAUAN RIAU SEBAGAI LEMBAGA PENGAWAS PELAYANAN PUBLIK DI BATAM
}

\author{
Emillia Dwi Setiawati Sianipar ${ }^{1}$
}

\begin{abstract}
The presence of the Ombudsman of the Republic of Indonesia is expected to be able to oversee the delivery of public services for the realization of an effective and efficient, honest, clean, open state administration and free from corruption, collusion and nepotism. However, has the supervision of the Ombudsman of the Republic of Indonesia in particular in Batam been effective?

The purpose of this study is to analyze the problem factors and provide solutions to overcome the problems of the Ombudsman of the Republic of Indonesia Representative of the Riau Islands Province in completing reports and efforts to prevent maladministration in Batam City. By using the Law Effectiveness Theory by Soerjono Soekanto and Empirical Legal Research Methods through observations, interviews and questionnaires as the main data source and literature study as supporting data sources, the research results are obtained that the supervision of the Ombudsman of the Republic of Indonesia Representative of the Riau Islands Province in Batam City has not been effective .

Problem factors of the Ombudsman of the Republic of Indonesia Representatives of the Riau Islands Province in overseeing public services in Batam City, namely: lack of human resources, lack of budget, lack of report identification, legal uncertainty, lack of support for public service providers, lack of coordination and cooperation between the Ombudsman and public service providers and lack of public awareness. Based on these problems, the researcher's suggestion as a recommendation is that the duties and functions of the Ombudsman run more effectively in accordance with the mandate of the Law, namely: by revising UUORI and implementing regulations for legal certainty, adding to the budget of the Indonesian Ombudsman Representative of the Riau Islands Province, Improving Quality RI Ombudsman HR Representatives of the Riau Islands Province, held cooperation with public service providers, and actively held socialization to the community.
\end{abstract}

Keywords: Ombudsman, Maladministration, Public Services, Effectiveness, Batam City.

\footnotetext{
${ }^{1}$ Fakultas Hukum Universitas Internasional Batam
} 


\section{A. Latar Belakang Masalah}

Konstitusi mendelegasikan bahwa tujuan didirikannya NKRI, ialah guna meningkatkan kesejahteraan umum serta mencerdaskan kehidupan bangsa. Sebagaimana yang tertuang dalam alinea keempat konstitusi yang bertuliskan: "Kemudian daripada itu untuk membentuk suatu Pemerintahan Negara Indonesia yang melindungi segenap bangsa Indonesia dan seluruh tumpah darah Indonesia dan untuk memajukan kesejahteraan umum, mencerdaskan kehidupan bangsa...". Untuk mewujudkannya, Negara wajib memenuhi hajat hidup orang banyak melalui penyelenggaraan pelayanan publik berkualitas yang mendorong terpenuhinya keperluan dasar serta hak-hak asasi setiap penduduk masyarakat berupa pelayanan jasa, barang dan administrasi. Rumusan serupa juga tampak pada Pasal 27 UUD NRI Tahun 1945, yang mana seluruh penduduk masyarakat memiliki hak atas pencaharian dan nafkah yang memadai guna kemanusiaan, serta Pasal 31 UUD NRI Tahun 1945 yang berisikan mengenai pelayanan edukasi, Pasal 33 UUD NRI Tahun 1945 yang mana pelayanan publik terhadap sumber daya alam haruslah digunakan terhadap sebesar-besarnya kemakmuran rakyat, serta Pasal 34 UUD NRI Tahun 1945 yang menyatakan bahwa fakir miskin juga anakanak telantar diurus oleh Negara. ${ }^{2}$

Dalam rangka mendistribusikan kesejahteraan tersebut, maka negara menyelenggarakan pelayanan publik kepada seluruh masyarakat. Menurut Undang-Undang Nomor 25 tahun 2009 tentang Pelayanan Publik, pelayanan publik ialah "kegiatan atau rangkaian kegiatan dalam rangka pemenuhan kebutuhan pelayanan sesuai dengan peraturan perundangundangan bagi setiap warga negara dan penduduk atas barang, jasa, dan/atau pelayanan administratif yang disediakan oleh penyelenggara pelayanan publik". Sebagaimana diatur dalam Pasal 5 Undang-Undang Undang-Undang Nomor 25 tahun 2009 tentang Pelayanan Publik, ruang lingkup pelayanan publik mencakup pelayanan barang, jasa maupun pelayanan administratif. Berdasarkan itu, pelayanan publik turut meliputi bidang pendidikan, usaha, pekerjaan, pengajaran, perumahan, informasi, komunikasi, perhubungan, kesehatan, jaminan sosial, perbankan, lingkungan hidup, energi, pariwisata serta sumber daya alam.

Peranan aparatur pemerintah dalam melayani masyarakat merupakan keterlibatan fungsi mereka guna terwujudnya suatu kesejahteraan masyarakat sesuai dengan cita-cita negara. Oleh karenanya, peranan aparatur pemerintah untuk melayani masyarakat sangat penting guna penentuan sejauh mana pemerintahan sanggup memberikan suatu pelayanan yang sebaik-baiknya kepada setiap masyarakat tanpa terkecuali. Dalam rangka memajukan kualitas berikut memberikan jaminan pelayanan

${ }^{2}$ Ombudman Republik Indonesia Perwakilan Provinsi Kepulauan Riau, "Bahan Bacaan Peserta Training of Trainer Sahabat Ombudsman Perwakilan Kepulauan Riau di Kabupaten Karimun” (Batam: Ombudsman Republik Indonesia Perwakilan Provinsi Kepulauan Riau, 2018), hlm. 1. 
publik serta guna melindungi tiap warga negara juga penduduk dari penyalahgunaan kekuasaan dalam suatu penyelenggaraan pelayanan publik, maka Indonesia telah membentuk sebuah lembaga pengawas penyelenggaraan pelayanan publik melalui Undang-Undang Nomor 37 Tahun 2008 tentang Ombudsman Republik Indonesia ( UU Ombudsman). ${ }^{3}$

Berdasarkan UU Ombudsman, pengertian Ombudsman ialah "Lembaga Negara yang mempunyai kewenangan mengawasi penyelenggaraan Pelayanan Publik baik yang diselenggarakan oleh penyelenggara negara dan pemerintahan termasuk yang diselenggarakan oleh Badan Usaha Milik Negara, Badan Usaha Milik Daerah, dan Badan Hukum milik Negara serta Badan Swasta atau perseorangan yang diberi tugas menyelenggarakan pelayanan publik tertentu yang sebagian atau seluruh dananya bersumber dari anggaran pendapatan dan belanja Negara dan/atau anggaran pendapatan dan belanja daerah". ${ }^{4}$ Ombudsman RI yang dulunya disebut sebagai Komisi Ombudsman Nasional (atau yang selanjutnya disebut KON) berdasarkan suatu Keputusan Presiden pada tahun 2000, dibentuk berdasarkan maksud untuk mencapai tercipta serta berkembangnya suatu keadaan yang kondusif pada pelaksanaan tugas pemberantasan $\mathrm{KKN}$, peningkatan perlindungan atas hak-hak warga negara supaya mendapat suatu pelayanan publik, serta terciptanya suatu kesejahteraan dan keadilan bagi setiap masyarakat. ${ }^{5}$

Ketika belum didirikannya KON, masyarakat dalam mengadukan suatu pelayanan publik menyampaikan aduannya tersebut hanya pada Instansi terlapor dan penanganannya juga acap kali dilaksanakan oleh pejabat terlapor tesebut sehingga oleh karenanya masyarakat belum mendapatkan suatu perlindungan yang patut. Disamping itu, penyelesaian perkara atas permasalahan pelayanan publik selama ini hanya melalui pengadilan dengan cara gugatan. Upaya itu tentu membutuhkan waktu penyelesaian perkara yang memakan waktu lama serta biaya yang banyak. Oleh karena itu, dibutuhkan suatu lembaga yang bersifat mandiri yang dalam hal ini disebut Ombudsman guna menyelesaikan aduan dan/atau laporan atas pelanggaran pelayanan publik secara mudah serta tanpa adanya pungutan biaya. Ombudsman tersebut bersifat bebas dari campur tangan kekuasaan lainnya guna melaksanakan fungsi dan tanggungjawabnya. ${ }^{6}$

Berdasarkan Undang-Undang Ombudsman RI, Ombudsman memiliki tugas: "1. Menerima laporan dugaan maladministrasi penyelenggara pelayanan publik; 2. Melakukan pemeriksaan laporan; 3. Menindaklanjuti laporan; 4. Melakukan investigasi atas prakarsa sendiri; 5. Melakukan koordinasi/kerjasama dengan lembaga negara/lembaga

\footnotetext{
${ }^{3}$ Ibid.

${ }^{4}$ Indonesia, Undang-undang Ombudsman Republik Indonesia, UU No.37 tahun 2008, Ps.1.

${ }^{5}$ Indonesia, Undang-undang Ombudsman Republik Indonesia, UU No.37 tahun 2008, Ketentuan Umum.

${ }^{6}$ Ibid.
} 
pemerintahan/lembaga kemasyarakatan/perorangan; 6. Membangun jaringan kerja; 7. Melakukan upaya pencegahan maladmistrasi dalam penyelenggaraan pelayanan publik, dan; 8. Melakukan tugas lain yang diberikan Undang-Undang". 7

Maladministrasi sebagaimana tertuang dalam Pasal 1 angka 3 UU Ombudsman, berarti: "perilaku atau perbuatan melawan hukum, melampaui wewenang, menggunakan wewenang untuk tujuan lain dari yang menjadi tujuan wewenang tersebut, termasuk kelalaian atau pengabaian kewajiban hukum dalam penyelenggaraan pelayanan publik yang dilakukan oleh Penyelenggara Negara dan pemerintahan yang menimbulkan kerugian materiil dan/atau immateriil bagi masyarakat dan orang perseorangan". 8 Sesuai dengan Peraturan Ombudsman Nomor 26 tahun 2017, terdapat 10 (sepuluh) macam bentuk dari Maladministrasi, yakni: Tidak memberikan pelayanan, Penundaan berlarut, Penyalahgunaan wewenang, Tidak kompeten, Penyimpangan prosedur, Tidak patut, Permintaan imbalan, Diskriminasi, Berpihak dan Konflik kepentingan.

Guna melaksanakan fungsi dan tanggungjawabnya, Ombudsman dapat mendirikan Perwakilan Ombudsman di wilayah Provinsi maupun Kota/Kabupaten. ${ }^{9}$ Pada provinsi Kepulauan Riau, Ombudsman Perwakilan telah dibentuk dari tahun 2012 lalu. ${ }^{10}$ Walaupun sudah berdiri sejak tahun 2000, ternyata mayoritas mayarakat Indonesia masih belum mengenal bahkan tak mengetahui perihal adanya Ombudsman sebagai lembaga negara pengawas pelayanan publik. ${ }^{11}$ Masyarakat juga tidak mengetahui perihal apa yang dimaksud dengan maladministrasi serta apabila suatu pelanggaran maladministrasi yang dilakukan oleh suatu penyelenggara pelayanan publik dapat dilaporkan kepada Ombudsman. ${ }^{12}$

Di provinsi Kepulauan Riau, Ombudsman Republik Indonesia dianggap sebagai pengumpul kasus pelayanan publik yang seolah pengaduan dari masyarakat tidak ada yang ditindaklanjuti dan tidak ada hasil yang disampaikan ke pengadu ataupun masyarakat atas hasil dari

${ }^{7}$ Ombudman Republik Indonesia Perwakilan Provinsi Kepulauan Riau, Op.Cit., hlm. 11-12.

${ }^{8}$ Indonesia, Undang-undang Ombudsman Republik Indonesia, UU No.37 tahun 2008, Ps. 1 angka 3.

9 Indonesia, Peraturan Pemerintah Pembentukan, Susunan, dan Tata Kerja Perwakilan Ombudsman Republik Indonesia di Daerah, PP No.21 tahun 2011, Ps.2

10 Kartika Kwartya, "Ombudsman Buka Kantor Perwakilan di Batam", http://batam.tribunnews.com/2012/02/28/ombudsman-buka-kantor-perwakilan-di-batam, diakses pada 26 April 2018.

11 Fikri Faqih, "Banyak masyarakat dinilai belum paham apa itu Ombudsman", https://www.merdeka.com/peristiwa/banyak-masyarakat-dinilai-belum-paham-apa-ituombudsman.html, diakses pada 3 Desember 2018.

12 Fachri Fachrudin, "Masyarakat Belum Paham Maladministrasi Bisa Dilaporkan ke Ombudsman",

https://nasional.kompas.com/read/2017/06/19/13113131/masyarakat.belum.paham.maladministras i.bisa.dilaporkan.ke.ombudsman, diakses pada 3 Desember 2018. 
pengaduan yang disampaikan tersebut. ${ }^{13}$ Selain itu, kompetensi pegawai pelayan publik di Pemerintah Provinsi Kepulauan Riau dinilai masih rendah. Hal itu diketahui dari hasil penelitian Ombudsman Republik Indonesia. Akibatnya Wilayah Provinsi Kepulauan Riau masuk dalam zona merah. Penelitian ini dilakukan di 22 Provinsi, 44 Kota dan 106 Kabupaten dan di publikasikan di Kantor Ombudsman Republik Indonesia di Jakarta pada Rabu, 22 Februari 2018. ${ }^{14}$ Dari segi laporan yang diterima, Ombudsman Republik Indonesia Perwakilan Provinsi Kepri memperoleh sebanyak 155 laporan di tahun 2017, jumlah laporan ini bertambah apabila dibandingkan dengan tahun 2016 yang berjumlah 140 laporan. Terhadap jumlah laporan di provinsi Kepri tersebut, jumlah laporan terbanyak pada tahun 2017 bersumber dari Kota Batam yang menyumbang sebesar 129 laporan. ${ }^{15}$

Berdasarkan latar belakang pemikiran tersebut, penulis tertarik untuk melakukan penelitian dan menulis jurnal dengan judul: "Efektivitas Ombudsman Republik Indonesia Perwakilan Provinsi Kepulauan Riau sebagai Lembaga Pengawas Pelayanan Publik di Kota Batam". Rumusan masalah dalam penelitian ini ada tiga yakni : (1) Bagaimana Efektivitas Ombudsman Republik Indonesia Perwakilan Provinsi Kepulauan Riau sebagai Lembaga Pengawas Pelayanan Publik di Kota Batam? (2) Faktor apa sajakah yang menjadi permasalahan Lembaga Ombudsman Republik Indonesia Perwakilan Provinsi Kepulauan Riau dalam mengawasi pelayanan publik di Kota Batam? (3) Bagaimana Solusi yang tepat dalam mengatasi permasalahan Lembaga Ombudsman Republik Indonesia Perwakilan Provinsi Kepulauan Riau dalam mengawasi pelayanan publik di Kota Batam?

\section{B. Metode Penelitian}

Penelitian ini menggunakan metode penelitian hukum empiris yang mencakup penelitian terhadap identifikasi hukum dan penelitian terhadap efektivitas hukum. ${ }^{16}$ Efektivitas hukum adalah suatu kemampuan hukum untuk menciptakan atau melahirkan keadaan atau situasi yang dikehendaki oleh hukum atau diharapkan oleh hukum. ${ }^{17}$

\footnotetext{
13 Admin, “Ombudsman Kepri Jangan Jadi Pengumpul Kasus Pelayanan Publik", https://solusihukum.com/ombudsman-kepri-jangan-jadi-pengumpul-kasus-pelayanan-publik/, diakses pada 3 Desember 2018.

14 Jun, "Pak Gubernur, Kepri Masuk Zona Merah", https://batampos.co.id/2018/02/22/pakgubernur-kepri-masuk-zona-merah/, diakses 3 Desember 2018.

15 Messa Haris, "Pengaduan ke Ombudsman terbanyak dari Batam", https://kepri.antaranews.com/berita/46976/pengaduan-ke-ombudsman-terbanyak-dari-batam, diakses pada 4 Desember 2018.

16 Mukti Fajar dan Yulianto Achmad, Dualisme Penelitian Hukum. Normatif dan Empiris, (Yogyakarta: Pustaka Pelajar, 2010), hlm 153.

${ }^{17}$ W. Yudho dan H. Tjandrasari, Efektivitas Hukum dalam Masyarakat, (Jakarta: Majalah Hukum dan pembangunan, UI Press, 1987), hlm. 59.
} 
Soerjono Soekanto mengatakan bahwa efektif adalah taraf sejauh mana suatu kelompok dapat mencapai tujuannya. Hukum dapat dikatakan efektif jika terdapat dampak hukum yang positif, pada saat itu hukum mencapai sasarannya dalam membimbing ataupun merubah perilaku manusia sehingga menjadi perilaku hukum. ${ }^{18}$ Selanjutnya terdapat 5 (lima) faktor untuk menguji Efektivitas Hukum, yakni: Faktor Hukumnya Sendiri, Faktor Penegakan Hukum, Faktor Sarana dan Fasilitas, Faktor Masyarakat serta Faktor Kebudayaan. ${ }^{19}$

Jenis data dalam Penelitian ini terbagi dua, yaitu data primer sebagai sumber data utama dan data sekunder sebagai sumber data pendukung. Data Primer berasal dari Wawancara dengan Kepala Pewakilan Ombudsman Provinsi Kepulauan Riau, Observasi ke Kantor Ombudsman Kepulauan Riau serta Kuesioner yang disebarkan kepada masyarakat di seluruh kecamatan di Kota Batam. Data Sekunder diperoleh dari UndangUndang, Buku, Jurnal, dan sebagainya.

Selanjutnya, data yang peneliti peroleh dianalisis menggunakan metode analisis data kualitatif yang tergantung pada sifat data yang dikumpulkan. ${ }^{20}$ Sifat data juga bersifat monografis karena pengumpulan data hanya dilakukan di Kota Batam.

\section{Hasil Penelitian dan Pembahasan}

\section{Hasil Penelitian}

\section{a. Gambaran Umum Ombudsman Republik Indonesia Perwakilan Provinsi Kepulauan Riau}

Pranata Ombudsman berasal dari sistem pemerintahan negara Swedia. ${ }^{21}$ Menurut Claes Ekludh yang dulunya pernah menjadi Ketua Ombudsman di Swedia, tahun 1713 merupakan prototype (awal mula) lahirnya lembaga Ombudsman melalui hadirnya Raja yang dulunya disebut King's Ombudsman yang diwujudkan oleh Raja Charles XII yang disebut sebagai Chancellor of Jutitie (Justitiekanseler). ${ }^{22}$

Jadi, awal mula maksud dibentuknya Ombudsman ialah untuk melakukan pengawasan kepada badan-badan peradilan berikut organ-organ pemerintah atau organ-organ administrasi supaya dalam melaksanakan tugas dan wewenangnya selaras dengan aturan hukum yang berlaku. Selanjutnya, Ombudsman dapat disebut sebagai perwakilan dari parlemen guna mengadakan

\footnotetext{
${ }^{18}$ Soerjono Soekanto, Efektivitas Hukum dan Penerapan Sanksi, (Bandung : CV. Ramadja Karya, 1988), hlm. 80.

${ }^{19}$ Soerjono Soekanto, Faktor-Faktor yang Mempengaruhi Penegakan Hukum (Jakarta: PT. Raja Grafindo Persada, 2008), hlm. 8.

${ }^{20}$ Zainuddin Ali, Sosiologi Hukum, (Jakarta: Sinar Grafika, 2006), hlm. 22.

21 Galang Asmara, Hukum Kelembagaan Negara, Cet.2, Yogyakarta: LaksBang PRESSindo, 2016) hlm. 6.

${ }^{22}$ Ibid.
} 
pengawasan terhadap perilaku aparat-aparat peradilan dan pemerintahan. Selanjutnya Pranata Ombudsman tersebut mulai dikenal dan tiru oleh negara-negara lainnya seperti Firlandia, Denmark, Kanada, Perancis, India dan lainnya. ${ }^{23}$

Di Indonesia Ombudsman lahir pada masa pemerintahan B.J. Habibie yang disebut sebagai tahap rintisan dan dilanjutkan oleh masa pemerintahan K.H. Abdurrahman Wahid (Gus Dur) yang disebut sebagai tahap pembentukan atau pilar sejarah berdirinya Ombudsman melalui Keputusan Presiden Nomor 40 Tahun 2000 tentang Komisi Ombudsman Nasional. Awal dibentuk, Ombudsman berbentuk Komisi. Pada tahun 2008 barulah kemudian Ombudsman disebut sebagai Lembaga Negara melalui hadirnya Undang-Undang Nomor 37 Tahun 2008 tentang Ombudsman Republik Indonesia (yang selanjutnya disebut dengan UUORI).

Tugas Ombudsman terbagi 2 (dua), yakni: (1) Menyelesaikan Laporan Maladministrasi Pelayanan Publik; dan (2) Melakukan Upaya Pencegahan Maladministrasi Pelayanan Publik. 24 Terdapat 10 (sepuluh) jenis maladministrasi menurut, yaitu: Penundaan berlarut, Tidak memberikan pelayanan, Tidak kompeten, Penyalahgunaan wewenang, Permintaan imbalan, Penyimpangan prosedur, Bertindak Tidak patut (tidak layak), Berpihak, Konflik kepentingan, dan Diskriminasi.25

Terdapat 3 (tiga) tahap penyelesaian laporan di Ombudsman Republik Indonesia, yakni: Tahap Penerimaan dan Verifikasi Laporan, Tahap Pemeriksaan serta Tahap Resolusi dan Monitoring sebagai berikut

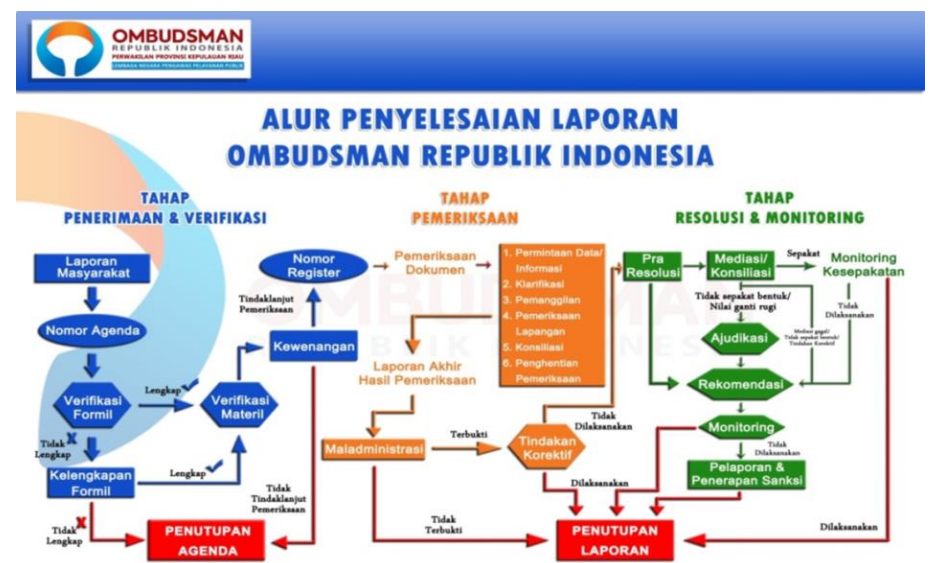

Gambar Alur Penyelesaian Laporan Ombudsman Republik Indonesia

23 Ibid.

${ }^{24}$ Indonesia, Undang-Undang Republik Indonesia, UU No. 37 Tahun 2008, Ps. 7.

25 Peraturan Ombudsman Republik Indonesia No. 26 Tahun 2017 tentang Tata Cara Penerimaan, Pemeriksaan, Dan Penyelesaian Laporan, pasal 11. 


\section{b. Data Penelitian di Ombudsman Republik Indonesia Perwakilan Provinsi Kepulauan Riau}

Berdasarkan data statistik Ombudsman Perwakilan Provinsi Kepulauan Riau diketahui bahwa Instansi yang paling sering dilaporkan oleh masyarakat ialah Pemerintah Daerah (33\%), Kepolisian (20\%) disusul BUMN/BUMD (13\%). Adapun jumlah laporan Ombudsman adalah sebanyak 146 laporan (2018), 155 laporan (2017) dan 140 laporan (2016) dengan jenis maladministrasi sebagai berikut:

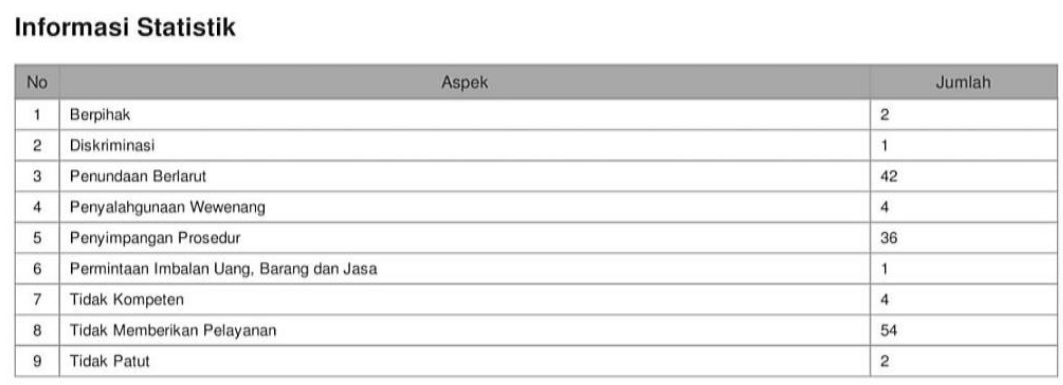

cindy.pardede | 2019/01/15 17:48:21

Tabel Informasi Statistik Dugaan Maladministrasi Tahun 2018

Informasi Statistik

\begin{tabular}{|c|l|l|}
\hline \multicolumn{2}{|c|}{ Nospek } & \multicolumn{2}{c|}{ Jumlah } \\
\hline 1 & Berpihak & 1 \\
\hline 2 & Diskriminasi & 1 \\
\hline 3 & Penundaan Berlarut & 35 \\
\hline 4 & Penyalahgunaan Wewenang & 6 \\
\hline 5 & Penyimpangan Prosedur & 38 \\
\hline 6 & Permintaan Imbalan Uang, Barang dan Jasa & 4 \\
\hline 7 & Tidak Kompeten & 10 \\
\hline 8 & Tidak Memberikan Pelayanan & 51 \\
\hline 9 & Tidak Patut & 9 \\
\hline
\end{tabular}

cindy,pardede | 2019/01/15 17:49:03

Tabel Informasi Statistik Dugaan Maladministrasi Tahun 2017

Informasi Statistik

\begin{tabular}{|c|l|l|}
\hline \multicolumn{2}{|c|}{ No Aspek } & \multicolumn{1}{c|}{ Jumlah } \\
\hline 1 & Diskriminasi & 1 \\
\hline 2 & Penundaan Berlarut & 34 \\
\hline 3 & Penyalahgunaan Wewenang & 10 \\
\hline 4 & Penyimpangan Prosedur & 41 \\
\hline 5 & Permintaan Imbalan Uang, Barang dan Jasa & 5 \\
\hline 6 & Tidak Kompeten & 2 \\
\hline 7 & Tidak Memberikan Pelayanan & 32 \\
\hline 8 & Tidak Patut & 15 \\
\hline
\end{tabular}

cindy.pardede | 2019/01/15 17:49:41

Tabel Informasi Statistik Dugaan Maladministrasi Tahun 2016 
Berdasarkan informasi statistik di atas, bisa dilihat bahwa jenis aduan maladministrasi oleh penyelenggara pelayanan publik tahun 2016-2018 yang paling banyak dilaporkan adalah (1) Tidak Memberikan Pelayanan (137 laporan); (2) Penyimpangan Prosedur (115); dan (3) Penundaan Berlarut (111 laporan).

Terdapat 5 (lima) cara dalam penyampaian laporan maladministrasi ke Ombudsman, yaitu dengan Mendatangi Kantor Ombudsman Langsung, Surat, Surat Elektronik (email), Media, Investigasi Inisiatif maupun Telepon. Berikut Informasi Statistik Ombudsman Kepulauan Riau mengenai Cara Penyampaian Laporan tahun 2016-2018:

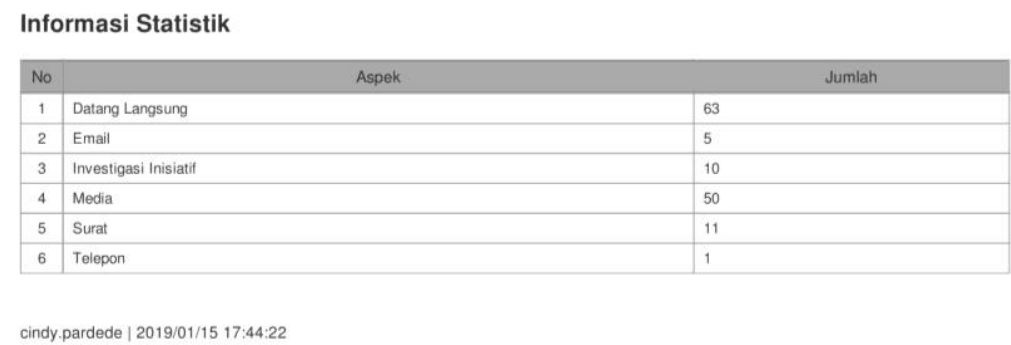

Tabel Informasi Statistik Cara Penyampaian Laporan Tahun 2016

Informasi Statistik
\begin{tabular}{|c|l|l|}
\hline No & \multicolumn{1}{l|}{ Aspek } & \\
\hline 1 & Datang Langsung & 75 \\
\hline 2 & Email & 5 \\
\hline 3 & Investigasi Inisiatif & 18 \\
\hline 4 & Media & 42 \\
\hline 5 & Surat & 15 \\
\hline
\end{tabular}

cindy.pardede | 2019/01/15 17:43:51

Tabel Informasi Statistik Cara Penyampaian Laporan Tahun 2017

\begin{tabular}{l} 
Informasi Statistik \\
\begin{tabular}{|c|l|l|}
\hline No & \multicolumn{1}{c|}{ Jumlah } \\
\hline 1 & Datang Langsung & 73 \\
\hline 2 & Email & 10 \\
\hline 3 & Investigasi Inisiatif & 23 \\
\hline 4 & Media & 12 \\
\hline 5 & Surat & 8 \\
\hline 6 & Telepon & 20 \\
\hline
\end{tabular} \\
cindy.pardede | 2019/01/15 17:43:16 \\
\hline
\end{tabular}

Tabel Informasi Statistik Cara Penyampaian Laporan Tahun 2018 
Berdasarkan data yang tertera di atas, bisa dilihat bahwa penyampaian laporan terbanyak pada kurun waktu tahun 20162018 adalah melalui mendatangi secara langsung kantor Ombudsman (211 laporan), media (104 laporan) diikuti dengan Investigasi Inisiatif Ombudsman (51 laporan).

Substansi permasalahan maladministrasi yang dilaporkan masyarakat ke Ombudsman Kepulauan Riau bermacam-macam, yakni: mengenai permasalahan Administrasi Kependudukan, Agama, Agraria/Pertanahan, Air Minum, Komisi/Lembaga Negara, Kesehatan, Imigrasi, Lingkungan Hidup, Perdagangan dan Industri, Asuransi/Jaminan Sosial, Perijinan (PTSP), Bea dan Cukai, Ketenagakerjaan, Pemukiman/Perumahan, Informasi Publik, Perhubungan/Infrastruktur, Kepolisian, Peradilan, Kejaksaan, Kepegawaian, Lembaga Permasyarakatan, Listrik, Pendidikan, Perbankan, SDA dan Energi, Telekomunikasi, Transportasi dan lain-lainnya. Berikut Informasi Statistik Substansi Laporan Tahun 2016-2018:

\section{Informasi Statistik}

\begin{tabular}{|c|c|c|}
\hline No & Aspek & Jumlah \\
\hline 1 & Administrasi Kependudkan & 9 \\
\hline 2 & Agraila/Pertanthan & 16 \\
\hline 3 & Ar Minum & 6 \\
\hline 4 & Asuransicduminan Sosial & 4 \\
\hline 5 & Bea dan Cokai & 3 \\
\hline 6 & Imigasi & 1 \\
\hline 7 & Inlomasi Publik & 10 \\
\hline 8 & Kejaksaan & 3 \\
\hline 9 & Kepegawaian & 5 \\
\hline 10 & Kepolisian & 12 \\
\hline 11 & Kesehatan & 8 \\
\hline 12 & Ketenagakerjaan & 3 \\
\hline 13 & Linghungan Hide & 6 \\
\hline 14 & Listrik & 1 \\
\hline 15 & Paipk & 8 \\
\hline 16 & PemukimanPenumahan & 4 \\
\hline 17 & Pendidlian & 13 \\
\hline 18 & Pendlan & 3 \\
\hline 19 & Petankan & 3 \\
\hline 20 & Pethubungarinifrastriktur & 14 \\
\hline 21 & Perilinan (PTSP) & 6 \\
\hline 22 & Petkanan & 1 \\
\hline 23 & Pedoburan & 2 \\
\hline 24 & Sumber Daya Alam dan Enegd & 1 \\
\hline 25 & Telekomunicasi & 1 \\
\hline
\end{tabular}

cindy.pardede | 2019/01/15 17:45:05

Tabel Informasi Statistik Substansi Laporan Tahun 2016 
Informasi Statistik

\begin{tabular}{|c|c|c|}
\hline No & Aspek & Jumlah \\
\hline 1 & Administrasi Kependudukan & 9 \\
\hline 2 & Agama & 1 \\
\hline 3 & Agralis:Pontanthan & 15 \\
\hline 4 & Air Minum & 4 \\
\hline 5 & AsumansiJuaminan Soside & 5 \\
\hline 6 & Bea dan Cukai & 2 \\
\hline 7 & Imigrasi & 4 \\
\hline 8 & Intormasi Pution & 5 \\
\hline 9 & Kopiaksatan & 2 \\
\hline 10 & Kepegemaian & 10 \\
\hline 11 & Kepolisian & 16 \\
\hline 12 & Kosehatan & s \\
\hline 13 & Ketensoskejajasn & 6 \\
\hline 14 & Komisillembaga Nogara & 2 \\
\hline 15 & Lembaga Pemasyarakatan & 2 \\
\hline 16 & Uingkungan Hidup & 3 \\
\hline 17 & Lisesk & 1 \\
\hline 18 & PomukimanPonumahan & 8 \\
\hline 19 & Pendidkan & 14 \\
\hline 20 & Peradilan & 1 \\
\hline 21 & Portankan & 1 \\
\hline 22 & Perdigangan din Industi & 4 \\
\hline 23 & Pentubunganinfrastindatur & 27 \\
\hline 24 & Perlinan (PTSP) & 4 \\
\hline 25 & Sumber Daya Alam den Energi & 1 \\
\hline 26 & Telekomunkasi & 2 \\
\hline 27 & Transportasil & 1 \\
\hline
\end{tabular}

cindy pardede | 2019/01/15 17:47:00

Tabel Informasi Statistik Substansi Laporan Tahun 2017

Informasi Statistik

\begin{tabular}{|c|c|c|}
\hline No & Aspek & Jumlah \\
\hline 1 & Administrasi Kependudikan & 16 \\
\hline 2 & Apraria/Pentanetran & 9 \\
\hline 3 & Air Minum & 4 \\
\hline 4 & Asurarsi/Jaminan Sosial & 2 \\
\hline 5 & Imigrasi & 4 \\
\hline 6 & Informasi Pubalik & 6 \\
\hline 7 & Kehreaman & 1 \\
\hline 8 & Kepegawaim & 16 \\
\hline 9 & Kepclision & 17 \\
\hline 10 & Kesenatan & 6 \\
\hline 11 & Kescjatteraan Sosial & 2 \\
\hline 12 & Keteneogkejamam & 4 \\
\hline 13 & Lotong & 1 \\
\hline 14 & Lemberga Pemasyarakatom & 2 \\
\hline 15 & Ungkungm Holup & 2 \\
\hline 16 & Listok & 1 \\
\hline 17 & Palak & 1 \\
\hline 18 & Podesaan & 1 \\
\hline 19 & PermikimanPonumahan & 1 \\
\hline 20 & Ponanaman Modid & 1 \\
\hline 21 & Pendidican & 15 \\
\hline 22 & Pergadaan Barang dan Jasa & 1 \\
\hline 23 & Poradlan & 6 \\
\hline 24 & Perbarkan & 4 \\
\hline 25 & Perdagangan den Industri & 1 \\
\hline 26 & Perhuoungan/nifrastruktur & 18 \\
\hline 27 & Peripinan (PTSP) & 2 \\
\hline 28 & Sumber Daya Alam dan Energy & 1 \\
\hline 20 & Transpontasi & 1 \\
\hline
\end{tabular}

cindy.pardede | 2019/01/15 17:47:51

Tabel Informasi Statistik Substansi Laporan Tahun 2018 
Bersumber dari data statistik tersebut, diperoleh kesimpulan bahwa aspek-aspek substansi laporan paling banyak pada kurun waktu tahun 2016-2018 adalah Perhubungan/Infrastruktur (59 laporan), Kepolisian (45 laporan), Pendidikan (42 laporan), Agraria/Pertanahan (40 laporan) dan Administrasi Kependudukan (34 laporan).

Selanjutnya, berikut ini pemaparan data Informasi Statistik Laporan Ombudsman Kepulauan Riau tahun 2012-2018 (per Agustus) mengenai penyelesaian jumlah pengaduan atau laporan yang masuk ke Ombudsman setiap tahunnya yang Peneliti dapatkan dari Ombudsman Republik Indonesia Perwakilan Provinsi Kepulauan Riau:

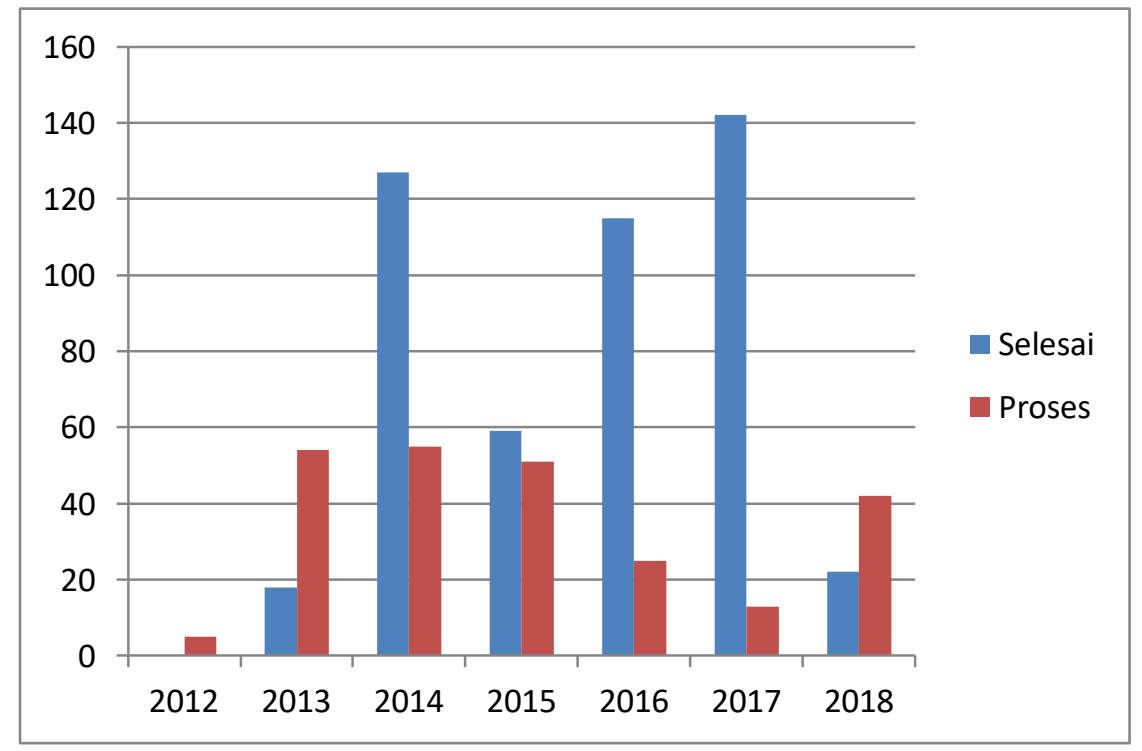

Gambar Data Jumlah Pengaduan di Ombudsman Kepri Tahun 2012-2018

\section{Informasi Statistik Laporan Ombudsman Kepulauan Riau}

\begin{tabular}{|c|c|c|c|}
\hline No & Tahun & Selesai & Proses \\
\hline 1 & 2012 & & 5 \\
\hline 2 & 2013 & 18 & 54 \\
\hline 3 & 2014 & 127 & 55 \\
\hline 4 & 2015 & 59 & 51 \\
\hline 5 & 2016 & 115 & 25 \\
\hline 6 & 2017 & 142 & 13 \\
\hline 7 & 2018 & 22 & 42 \\
\hline
\end{tabular}

Tabel Informasi Statistik Laporan Ombudsman Kepulauan Riau 
Melalui pemaparan data statistik di atas dapat diketahui bahwa total jumlah pengaduan Ombudsman Perwakilan Kepulauan Riau pada tahun 2012-2018 (per Agustus) ialah 728 laporan dengan total laporan selesai ialah sebanyak 483 laporan dan total laporan proses ialah sebanyak 245 laporan. Selanjutnya melalui hasil olah data, Peneliti memperoleh presentase penyelesaian laporan Ombudsman setiap tahunnya ialah sebesar $66,3 \%$ laporan. Sebaliknya jumlah laporan yang tidak diselesaikan atau proses penyelesaiannya dilanjutkan di tahun berikutnya ialah sebesar 33,7\% laporan.

\section{Hasil Pembahasan}

a. Efektivitas Ombudsman Republik Indonesia Perwakilan Provinsi Kepulauan Riau sebagai Lembaga Pengawas Pelayanan Publik di Kota Batam.

Berdasarkan teori Efektivitas Soerjono Soekanto yang dihubungkan dengan analisa dan fakta dilapangan yang peneliti dapatkan, maka ditemukan beberapa fakta permasalahan diantaranya: ${ }^{26}$

1) Faktor Hukum

Dari segi faktor Hukum terdapat beberapa permasalahanpermasalahan, yaitu: Pertama, rekomendasi dan ataupun surat-surat Ombudsman Republik Indonesia bersifat nonlegally Binding (tidak mengikat) terhadap institusi terkait; Kedua, tidak adanya kejelasan aturan hukum terkait apa yang dimaksud dengan tindakan korektif dan berapa lama batas waktu dalam pelaksanaan tindak korektif tersebut; serta Ketiga, tidak adanya aturan yang tegas mengenai batasan waktu dalam setiap tahapan alur penyelesaian laporan.

2) Faktor Penegakan Hukum

Dari segi faktor Penegakan Hukum terdapat beberapa permasalahan-permasalahan, yaitu: Pertama, Ombudsman belum dikenali oleh Penyelenggara Pelayanan Publik terkait dengan kewenangan Ombudsman dalam mengawasi mereka; Kedua, kurangnya jumlah personil keasistenan Ombudsman di wilayah Perwakilan Provinsi Kepulauan Riau; Ketiga, kurangnya dukungan anggaran oleh Pemerintah; serta Keempat, terhambatnya kinerja Ombudsman Perwakilan akibat Memorandum Ombudsman Pusat yang harus dilaksanakan.

26 Hasil Wawancara Peneliti dengan Bapak Lagat Parroha Patar Siadari selaku Kepala Ombudsman Republik Indonesia Perwakilan Kepulauan Riau pada 21 Desember 2018. 
3) Faktor Sarana dan Fasilitas

Dari segi faktor Sarana dan Fasilitas terdapat beberapa permasalahan-permasalahan, yaitu: Pertama, Tidak terpenuhinya fasilitas ruangan Kepala Perwakilan, Asisten dan Pegawai; Kedua, Tidak adanya Ruang Rapat Besar, Mushala, Ruang Laktasi, Toilet, Ruang Penyimpanan Barang dan Ruang Merokok; Ketiga, Kendaraan Dinas hanya berupa 1 (satu) buah mobil; Keempat, Tidak terpenuhinya perlengkapan pendukung.

4) Faktor Masyarakat dan Budaya

Dari segi faktor Masyarakat dan Budaya Peneliti menemukan permasalahan-permasalahan berdasarkan hasil kuesioner yang Peneliti sebarkan di seluruh kecamatan Kota Batam dengan total sebanyak 158 (seratus lima puluh delapan) Responden, yaitu: Pertama, masih banyaknya masyarakat Kota Batam yang belum mengenal Ombudsman dan belum mengetahui apa yang dimaksud dengan Maladministrasi Pelayanan Publik; Kedua, hampir seluruh masyarakat di Kota Batam mengaku pernah mengalami pelayanan publik yang tidak baik atau maladministrasi; Ketiga, hanya sebesar 3,2\% dari jumlah Responden yang melaporkan maladministrasi pelayanan publik. Sisanya menjawab tidak tahu harus melapor kemana dan memilih diam atau membiarkan perbuatan maladministrasi pelayanan publik tersebut.

b. Faktor-faktor Permasalahan Lembaga Ombudsman Republik Indonesia Perwakilan Provinsi Kepulauan Riau dalam mengawasi Pelayanan Publik di Kota Batam.

Dari hasil analisa dan fakta di lapangan, terdapat berbagai faktor yang memicu ketidakefektifan Ombudsman Republik Indonesia Perwakilan Provinsi Kepulauan Riau dalam mengawasi Pelayanan Publik di Kota Batam, yakni: ${ }^{27}$

1) Faktor Internal

Yang dimaksud dengan faktor internal ialah faktorfaktor permasalahan yang berasal dari Ombudsman sendiri sebagai Lembaga Pengawas Pelayanan Publik. Permasalahan-permasalahan tersebut, yakni: Pertama, Kurangnya Sumber Daya Manusia (SDM) berupa kurangnya jumlah asisten, kurangnya kemampuan asisten, kurangnya

Hasil Wawancara Peneliti dengan Bapak Lagat Parroha Patar Siadari selaku Kepala Ombudsman Republik Indonesia Perwakilan Kepulauan Riau pada 21 Desember 2018. 
kekompakan Tim serta kurangnya pelatihan yang menyebabkan tidak efektifnya Ombudsman dalam melaksanakan fungsinya; Kedua, Kurangnya Anggaran yang menyebabkan kurangnya Fasilitas dan Sarana serta tidak maksimalnya Ombudsman Kepri dalam menjalankan fungsinya; Ketiga, Tidak adanya identifikasi laporan berupa pembagian kategori laporan masyarakat menjadi 3 (tiga) bagian, yaitu: Ringan, Sedang, dan Berat agar penyelesaian laporan lebih efektif; serta Keempat, berupa Ketidakpastian Hukum akibat peraturan perundang-undangan serta peraturan Ombudsman yang tidak konsisten dan tidak jelas.

2) Faktor Eksternal

Yang dimaksud dengan faktor eksternal ialah faktorfaktor permasalahan yang berasal dari luar Ombudsman sebagai Lembaga Pengawas Pelayanan Publik. Permasalahan-permasalahan tersebut, yakni: Pertama, Kurangnya Dukungan Penyelenggara Pelayanan Publik berupa masih kurang pahamnya Penyelenggara Pelayanan Publik terhadap kewenangan Ombudsman, kurangnya Pengawas Internal dalam melaksanakan fungsinya, belum semua Kantor Penyelenggara Pelayanan Publik menyediakan pos penerimaan dan penyelesaian pengaduan, adanya ketentuan lain yang mengatur di sejumlah instansi vertikal bahwa yang berhak memberikan klarifikasi ialah Kantor Pusat, serta masih kurangnya dukungan Pimpinan Instansi Terlapor sehingga laporan dilempar kesana-sini dan menyebabkan lambatnya penyelesaian laporan; Kedua, Kurangnya Koordinasi dan Kerjasama Ombudsman dengan Penyelenggara Pelayanan Publik; serta Ketiga, Kurangnya Kesadaran Masyarakat untuk menjadikan Ombudsman sebagai lembaga pengaduan pelayanan publik.

c. Solusi yang tepat dalam mengatasi permasalahan Lembaga Ombudsman Republik Indonesia Perwakilan Provinsi Kepulauan Riau dalam mengawasi Pelayanan Publik di Kota Batam.

Banyaknya faktor-faktor permasalahan seperti yang telah dijelaskan sebelumnya menyebabkan ketidakefektifan Ombudsman Republik Indonesia Perwakilan Provinsi Kepulauan Riau guna mengawasi pelayanan publik di Kota Batam. Dari permasalahan-permasalahan tersebut, agar pengawasan Ombudsman dapat berjalan efektif, maka dibutuhkan adanya solusi sebagai berikut: 
1) Revisi Undang-Undang Ombudsman Republik Indonesia dan Peraturan Pelaksana terkait demi kepastian hukum. Adapun bentuk perubahan hukum yang diperlukan, yakni: Pertama, perlunya penambahan Pasal dalam Undang-Undang Ombudsman Republik Indonesia dan/atau Peraturan Pelaksana terkait mengenai kewenangan Ombudsman dalam memberikan sanksi administratif kepada Terlapor serta aturan mengenai kekuatan eksekutorial bagi Ombudsman Perwakilan dalam Tindakan Korektif; Kedua, dibutuhkan kejelasan aturan Ombudsman terutama dalam hal pengertian dan mekanisme pelaksanaan Tindakan Korektif, RCO, serta Mediasi atau Konsiliasi; Ketiga, dibutuhkan tambahan peraturan dalam UUORI dan/atau Peraturan Pelaksana mengenai Identifikasi Laporan serta Jangka Waktu dan/atau Batas Waktu dalam penyelesaian laporan supaya penyelesaian laporan konsisten.

2) Menambah anggaran Ombudsman Republik Indonesia Perwakilan Provinsi Kepulauan Riau guna melaksanakan tugas penyelesaian laporan dan uapaya pencegahan maladministrasi serta guna melengkapi sarana dan fasilitas di Kantor Ombudsman.

3) Peningkatan kualitas SDM Ombudsman Republik Indonesia Perwakilan Provinsi Kepulauan Riau yang berupa pelatihan asisten yang berguna untuk meningkatkan kualitas asisten dan kerjasama tim, serta penambahan jumlah asisten sekurang-kurangnya 14 (empat belas) asisten untuk wilayah perwakilan Provinsi Kepulauan Riau.

4) Mengadakan kerjasama dengan penyelenggara pelayanan publik berupa Memorandum of Understanding (MOU) atau Perjanjian Kerjasama yang berisikan langkah kerjasama penyelesaian laporan dan perbaikan pelayanan publik atas aduan/laporan masyarakat, serta pengadaan pos pengaduan di setiap Kantor Pelayanan Publik.

5) Aktif Mengadakan Sosialisasi ke Masyarakat yang bertujuan untuk mengenalkan Ombudsman sebagai lembaga pelayanan publik serta mengenalkan apa itu maladministrasi kepada masyarakat.

\section{Kesimpulan}

Kesimpulan berdasarkan penelitian ini ialah Pertama, bahwa pengawasan Ombudsman Republik Indonesia Perwakilan Provinsi Kepulauan Riau di Kota Batam yang ditinjau berdasarkan Teori Efektivitas Hukum Soerjono Soekanto belum berjalan efektif. Kedua, bahwa faktor ketidakefektifan pengawasan Ombudsman Republik 
Indonesia Perwakilan Provinsi Kepulauan Riau di Kota Batam disebabkan oleh faktor internal dan eksternal, yakni: kurangnya SDM, kurangnya anggaran, tidak adanya identifikasi laporan, ketidakpastian hukum, kurangnya dukungan penyelenggara pelayanan publik, kurangnya kordinasi dan kerjasama Ombudsman dengan penyelenggara pelayanan publik, serta kurangnya kesadaran masyarakat. Ketiga, solusi agar pengawasan Ombudsman Republik Indonesia Perwakilan Provinsi Kepulauan Riau di Kota Batam dapat berjalan secara efektif sesuai dengan amanat Undang-Undang, yaitu: dengan revisi UUORI dan peraturan pelaksana demi kepastian hukum, menambah anggaran Ombudsman RI Perwakilan Provinsi Kepulauan Riau, Peningkatan Kualitas SDM Ombudsman RI Perwakilan Provinsi Kepulauan Riau, mengadakan kerjasama dengan penyelenggara pelayanan publik, serta aktif mengadakan sosialisasi ke masyarakat. 


\section{Daftar Pustaka}

\section{Buku:}

Ali, Zainuddin. Sosiologi Hukum. Jakarta: Sinar Grafika, 2006.

Asmara, G. Hukum Kelembagaan Negara, cetakan 2. Yogyakarta: LaksBang PRESSindo, 2016.

Soekanto, Soerjono. Efektivitas Hukum dan Penerapan Sanksi. Bandung : CV. Ramadja Karya, 1988.

Soekanto, Soerjono. Faktor-Faktor yang Mempengaruhi Penegakan Hukum. Jakarta: PT. Raja Grafindo Persada, 2008.

\section{Makalah Hukum:}

Ombudman Republik Indonesia Perwakilan Provinsi Kepulauan Riau. Bahan Bacaan Peserta Training of Trainer Sahabat Ombudsman Perwakilan Kepulauan Riau di Kabupaten Karimun. Makalah disampaikan pada Pelatihan Sahabat Ombudman Perwakilan Provinsi Kepulauan Riau, Hotel Aston Karimun, 25 Agustus 2018.

\section{Majalah Hukum:}

Tjandrasari, H dan W. Yudho. Efektivitas Hukum dalam Masyarakat. Jakarta: Majalah Hukum dan pembangunan, UI Press, 1987

\section{Internet:}

Admin. Ombudsman Kepri Jangan Jadi Pengumpul Kasus Pelayanan Publik”. https://solusihukum.com/ombudsman-kepri-jangan-jadipengumpul-kasus-pelayanan-publik/. Diakses pada 3 Desember 2018.

Admin, Pengaduan ke Ombudsman terbanyak dari Batam, http://www.ombudsman.go.id/perwakilan/news/r/pwk--pengaduanke-ombudsman-terbanyak-dari-batam. Diakses pada 10 Mei 2018.

Fachrudin, Fachri. Masyarakat Belum Paham Maladministrasi Bisa Dilaporkan ke Ombudsman. https://nasional.kompas.com/read/2017/06/19/13113131/masyaraka t.belum.paham.maladministrasi.bisa.dilaporkan.ke.ombudsman. Diakses pada 3 Desember 2018.

Faqih, Fikri. Banyak masyarakat dinilai belum paham apa itu Ombudsman. $\quad$ https://www.merdeka.com/peristiwa/banyakmasyarakat-dinilai-belum-paham-apa-itu-ombudsman.html. Diakses pada 3 Desember 2018.

Jun, Pak Gubernur, Kepri Masuk Zona Merah. https://batampos.co.id/2018/02/22/pak-gubernur-kepri-masukzona-merah/. Diakses 3 Desember 2018. 
Kwartya, Kartika. Ombudsman Buka Kantor Perwakilan di Batam, http://batam.tribunnews.com/2012/02/28/ombudsman-buka-kantorperwakilan-di-batam. Diakses pada 26 April 2018.

Pratama, Andi. Ombudsman Kepri Terima 46 Laporan, Terbanyak Aduan Pemda Setelah Itu Polisi, https://www.wartakepri.co.id/2018/06/27/ombudsman-kepriterima-46-laporan-terbanyak-aduan-pemda-setelah-itu-polisi/. Diakses pada 23 Juli 2018.

\section{Peraturan Perundang-Undangan:}

Undang-Undang Nomor 37 Tahun 2008 tentang Ombudsman Republik Indonesia (Lembaran Negara Republik Indonesia Tahun 2008 Nomor 139, Tambahan Lembaran Negara Nomor 4899).

Peraturan Pemerintah Nomor 21 Tahun 2011 tentang Pembentukan, Susunan, dan Tata Kerja Perwakilan Ombudsman Republik Indonesia di Daerah (Lembaran Negara Republik Indonesia Tahun 2011 Nomor 42).

Peraturan Ombudsman Republik Indonesia Nomor 26 Tahun 2017 tentang Tata Cara Penerimaan, Pemeriksaan, Dan Penyelesaian Laporan. 